medRxiv preprint doi: https://doi.org/10.1101/2021.08.18.21262223; this version posted August 24, 2021. The copyright holder for this preprint (which was not certified by peer review) is the author/funder, who has granted medRxiv a license to display the preprint in

All rights reserved. No reuse allowed without permission.

\title{
1 Distributed genetic architecture across the hippocampal formation implies 2 common neuropathology across major brain disorders
}

3 Shahram Bahrami ${ }^{1 *}$, Kaja Nordengen ${ }^{1}$, Alexey A. Shadrin ${ }^{1}$, Oleksandr Frei ${ }^{1}$, Dennis van der 4 Meer $^{1,2}$, Anders M. Dale ${ }^{3,4,5}$, Lars T. Westlye ${ }^{1,6}$, Ole A. Andreassen ${ }^{1}$, Tobias Kaufmann ${ }^{1,7^{*}}$

51 Norwegian Centre for Mental Disorders Research (NORMENT), Division of Mental Health and 6 Addiction, Oslo University Hospital \& Institute of Clinical Medicine, University of Oslo, Oslo, 7 Norway

82 School of Mental Health and Neuroscience, Faculty of Health, Medicine and Life Sciences, 9 Maastricht University, Maastricht, The Netherlands

103 Department of Radiology, School of Medicine, University of California, San Diego, CA, USA

114 Department of Neurosciences, University of California San Diego, La Jolla, CA 92037, USA

125 Center for Multimodal Imaging and Genetics, University of California at San Diego, La Jolla, CA, 1392037 , USA

146 Department of Psychology, University of Oslo, Oslo, Norway

157 Department of Psychiatry and Psychotherapy, Tübingen Center for Mental Health (TüCMH), 16 University of Tübingen, Tübingen, Germany

$17{ }^{*}$ Correspondence:

Shahram Bahrami, PhD \&
Norwegian Centre for Mental
Disorders Research, Oslo
University Hospital, PoBox 4956
Nydalen, Norway
shahram.bahrami@ medisin.uio.no

\author{
\& Tobias Kaufmann, PhD \\ Tübingen Center for Mental Health, \\ University of Tübingen, \\ Calwerstraße 14, 72076 Tübingen, Germany \\ Norwegian Centre for Mental Disorders Research \\ Oslo University Hospital, PoBox 4956 Nydalen, Norway \\ tobias.kaufmann@med.uni-tuebingen.de
}

18 Word count main text: $\underline{2575}$ | Word count abstract: $\underline{80}$

19 Number of figures: $\underline{3}$ |Number of references: $\underline{56}$ 
medRxiv preprint doi: https://doi.org/10.1101/2021.08.18.21262223; this version posted August 24, 2021. The copyright holder for this preprint (which was not certified by peer review) is the author/funder, who has granted medRxiv a license to display the preprint in All rights reserved. No reuse allowed without permission.

Distributed genetic architecture across the hippocampal formation | Bahrami et al.

Despite its major role in complex human behaviours across the lifespan, including memory

formation and decline, navigation and emotions, much of the genetic architecture of the

hippocampal formation is currently unexplored. Here, through multivariate genome-wide

loci with distributed associations across the hippocampal formation. We identified profound

genetic overlap with eight major developmental and degenerative brain disorders, where

hippocampal pathology.

The hippocampal formation on each side of the medial temporal lobes of the brain plays critical roles in spatial and episodic memory ${ }^{1,2}$, navigation ${ }^{3,4}$ emotions $^{5}$, and other complex human behaviours.

Consequently, impaired or lesion-induced loss of hippocampal functioning has tremendous and diverse impact on cognitive and emotional functions ${ }^{6,7}$, and the hippocampus has been extensively studied across a wide variety of diseases and traits, including trajectories of development and aging.

While previous volumetric magnetic resonance imaging (MRI) studies of the human hippocampus have primarily investigated volume of the structure as a whole, recent advancements into deriving its subdivisions through adaptive segmentation has allowed for a more fine-grained assessment across multiple subregions ${ }^{8}$. The hippocampal formation comprises the histologically distinguishable subfields of the hippocampus proper as well as the dentate gyrus with its own subfields, and the neocortical subiculum, presubiculum and parasubiculum. In all but the latter, the hippocampal formation is also divided into an anterior (head) and a posterior part (body). The various contributions to the function of the hippocampal formation differ along the septo-temporal axis, where for example the anterior part is known to contribute to anxiety-related behaviours and cost-benefit decision making while the posterior part is particularly involved in spatial processing ${ }^{5}$. Such a dichotomy between the hippocampal head and the hippocampal body is also evident from patterns of neurogenesis. For example, although neurogenesis continues throughout life in the dentate gyrus ${ }^{9}$, it is especially the process in its anterior part that has been linked to emotion regulation and appears of relevance for the behavioural effects of antidepressants ${ }^{10}$. A total of 19 subregion volumes can currently be segmented with MRI ${ }^{8}$. 
medRxiv preprint doi: https://doi.org/10.1101/2021.08.18.21262223; this version posted August 24, 2021. The copyright holder for this preprint (which was not certified by peer review) is the author/funder, who has granted medRxiv a license to display the preprint in All rights reserved. No reuse allowed without permission.

Distributed genetic architecture across the hippocampal formation | Bahrami et al.

The rate of hippocampal maturation and change throughout the lifespan may capture information relevant to the study of major psychiatric and neurological disorders, where the age at which individual neurophysiological trajectories diverge from the norm may reflect key characteristics of the underlying pathophysiology ${ }^{11}$. Indeed, the hippocampal formation is known to be involved in disorders with typical onset during neurodevelopment ${ }^{12}$, such as autism spectrum disorders (ASD), attention-deficit hyperactivity disorder (ADHD), schizophrenia (SCZ) and bipolar disorder (BIP), through its roles in perception, memory processes, modulation of executive function, emotion regulation, among others ${ }^{13-15}$. Furthermore, through its involvement in stress response, the hippocampal formation is potentially involved in migraine $(\mathrm{MIG})^{16}$ and tests of recollection memory indicate hippocampal dysfunction in major depression $(\mathrm{MD})^{17}$, both of which are disorders that can appear at any stage from adolescence to old age. Finally, the hippocampal formation is implied in diseases that primarily emerge during senescence such as Parkinson's disease (PD) and Alzheimer's disease (AD). Emerging data suggests a complex hippocampal crosstalk among the dopaminergic and other transmitter systems in PD, involved in adaptive memory and motivated behaviour ${ }^{18}$. Loss of hippocampal functions like navigation and episodic memory are core markers of $\mathrm{AD}$ and hippocampal atrophy is an established finding ${ }^{19,20}$. Taken together, the hippocampal formation is a central and interconnected structure that plays important roles in complex human behaviours and is implicated in a range of major psychiatric and neurological disorders across the lifespan.

The recent decade has brought significant progress towards a characterization of the genetic architecture of the hippocampal formation, from experimental manual mapping in mice $^{21}$ to brain imaging based genome-wide-association studies (GWAS) in humans ${ }^{22-24}$, revealing fifteen independent loci when studying individual hippocampal subfields ${ }^{24}$. Given the broad functional portfolio of the hippocampal formation, however, it is clear that much of the genetic architecture remains to be explored, calling for further studies and novel analytical approaches ${ }^{25}$. Recent work revealed a distributed genetic architecture of human brain anatomy $y^{26,27}$ and function ${ }^{28}$ and suggested that capitalizing on this distributed nature in a multivariate GWAS approach can significantly improve the discovery beyond standard GWAS approaches ${ }^{26}$. We hypothesized that the genetic architecture within the hippocampal 
medRxiv preprint doi: https://doi.org/10.1101/2021.08.18.21262223; this version posted August 24, 2021. The copyright holder for this preprint (which was not certified by peer review) is the author/funder, who has granted medRxiv a license to display the preprint in All rights reserved. No reuse allowed without permission.

Distributed genetic architecture across the hippocampal formation | Bahrami et al.

formation is distributed across its subregions and thus aimed to gain novel insights into the genetics of the hippocampal formation by deploying such multivariate GWAS approach. Further, given hippocampal involvement in major brain disorders across the lifespan, we used common neurological and psychiatric disorders as proxies for potential age-dependent hippocampal pathology, aiming to reveal gene variants potentially involving the hippocampus at different stages in life.

We accessed raw T1-weighted MRI data from 35,411 genotyped white British individuals (age range: aged $45-82$ years, mean: 64.4 years, sd: 7.5 years, $51.7 \%$ females) from the UK Biobank ${ }^{29}$ (permission no. 27412) and segmented the hippocampal formation into 19 subregions in addition to total hippocampus volume (sum of all subfields) using FreeSurfer $7.1^{8}$. For each of these, we calculated the average volume between the left and right hemisphere and residualized for age, age squared, sex, scanning site, a proxy of image quality, intracranial volume and the first 20 genetic principal components. The resulting residuals were used in genetic analyses, feeding the 19 subregions alongside whole hippocampus volume into multivariate GWAS $\left(\right.$ MOSTest $\left.^{26}\right)$.

\section{Multivariate approach identifies 173 loci associated with hippocampal formation}

In line with our hypothesis, we found strong support of a distributed genetic architecture in the hippocampal formation. Multivariate GWAS revealed 173 unique genetic loci with distributed associations across the hippocampal formation. The upper panel of Figure 1 depicts the corresponding multivariate statistics, highlighting the polygenic architecture of the hippocampal formation. For each of the 173 loci, the lower panel of Figure 1 depicts statistics from univariate GWASs of individual hippocampal subregions. The elevated univariate statistics for multiple hippocampal subregions in some of the same loci supports a distributed genetic architecture across the hippocampal formation, which is also supported by genetic correlation analysis of the univariate GWASs of the individual subregions (Supplementary Figure 1, Supplementary Table 1). Whereas the strongest hits among our 173 discovered loci are also implied in univariate analysis, a large share of the 173 loci showed elevated yet not genome-wide significant effects at univariate level. By capitalizing on these distributed effects across subregions, the multivariate approach boosted discovery. Supplementary Table 2 
medRxiv preprint doi: https://doi.org/10.1101/2021.08.18.21262223; this version posted August 24, 2021. The copyright holder for this preprint (which was not certified by peer review) is the author/funder, who has granted medRxiv a license to display the preprint in All rights reserved. No reuse allowed without permission.

Distributed genetic architecture across the hippocampal formation | Bahrami et al.

101 provides additional details on the 173 discovered loci, most of which were not identified in previous

102 hippocampus GWAS. Supplementary Figure 2 depicts corresponding quantile-quantile (Q-Q) plots,

103 including one from permutation testing that confirms validity of the multivariate test statistic.

104 Supplementary Figure 3 covers additional validations, including a cross-ethnic replication attempt in an independent set of 5262 individuals with non-white ethnicity.

106

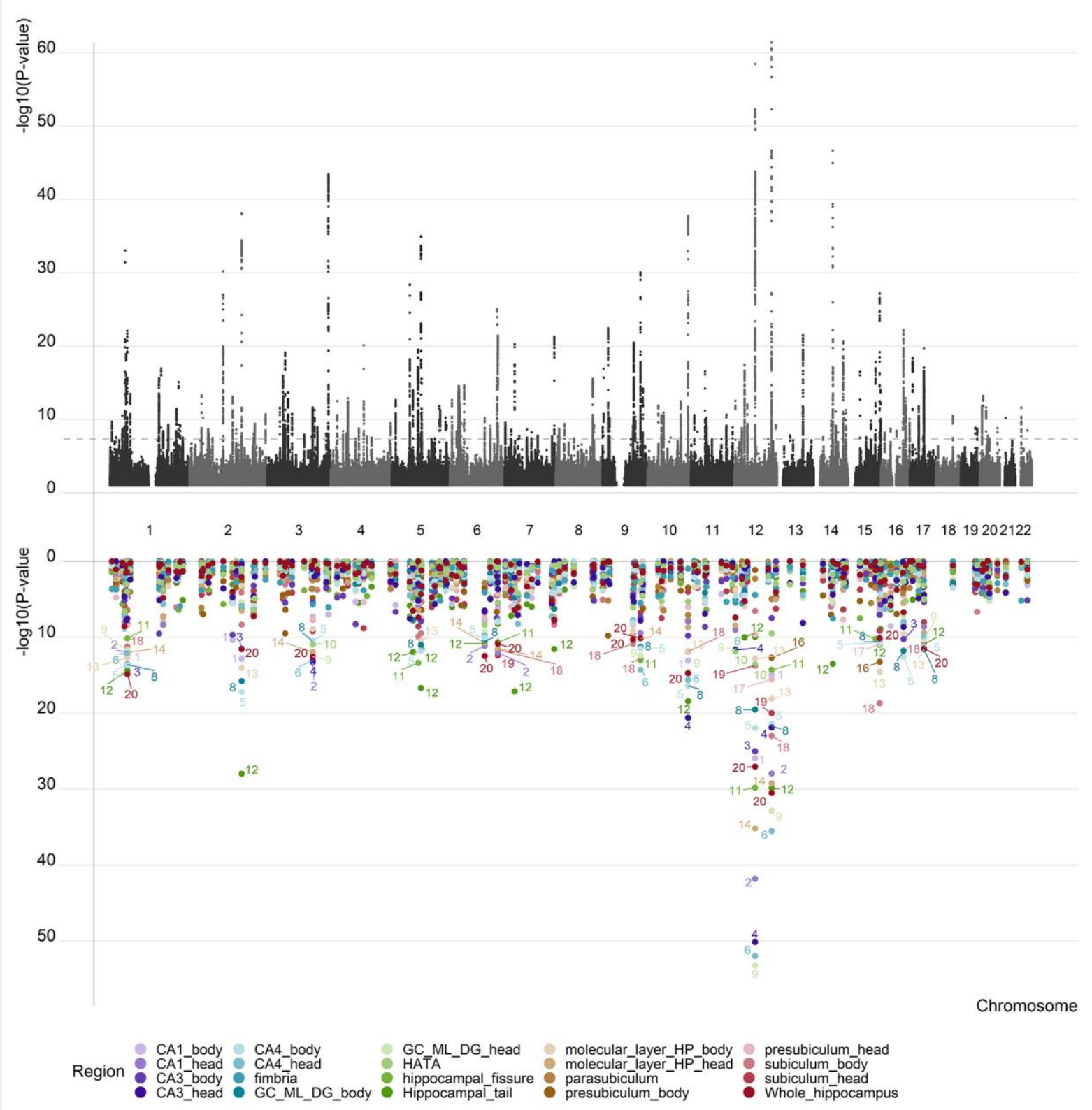

108 Figure 1. The multivariate framework discovered 173 independent loci significantly associated

109 with the hippocampal formation. The upper panel illustrates the multivariate GWAS statistics for the

110 entire formation with 173 significant loci. The lower panel for each of the 173 unique loci depicts the 111 corresponding statistics from univariate GWASs of single subregions (one colour per subregion). 
medRxiv preprint doi: https://doi.org/10.1101/2021.08.18.21262223; this version posted August 24, 2021. The copyright holder for this preprint (which was not certified by peer review) is the author/funder, who has granted medRxiv a license to display the preprint in All rights reserved. No reuse allowed without permission.

Distributed genetic architecture across the hippocampal formation | Bahrami et al.

113 Functional mapping and annotation identifies 69 genes robustly associated with hippocampal

\section{4 formation}

115 We functionally annotated all candidate SNPs $(\mathrm{n}=21430)$ that were in linkage disequilibrium $(\mathrm{r} 2 \geq 0.6)$

116 with one of the independent significant SNPs using Functional Mapping and Annotation of GWAS

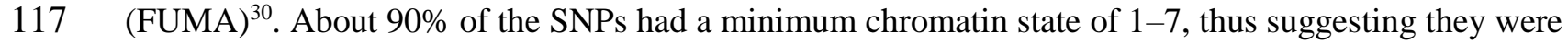

118 in open chromatin regions ${ }^{31,32}$, and $5.6 \%$ were in regulatomeDB category 1 or 2 , suggesting potential

119 regulatory function ${ }^{31}$ (Supplementary Figure 4A-B). A majority of these SNPs were intronic (50.7\%)

120 or intergenic (29.9\%) and 1.0\% were exonic (Supplementary Figure 4C).

We mapped the 173 loci implied for the hippocampal formation to 813 genes based on different mapping strategies (positional, expression quantitative trait loci (eQTL), chromatin state mapping and MAGMA analysis). Out of these, 69 genes were identified by all four mapping strategies (Figure 2), supporting robustness of these findings. Supplementary Tables 3-6 provide additional details. Among the genes mapped from loci with strongest GWAS effects we found LEMD3 (also known as MANI) and RNFT2 (also known as TMEM118), both important for immune regulation ${ }^{33,34}$. Another strong hit was $F A M 53 B$, known for its important roles in neurodevelopment such as control of cell proliferation and maintenance of a pluripotent state ${ }^{35}$. Rs 2151909 on chromosome 6 was mapped to six different genes by all four mapping strategies: KATNA1, LATS1, NUP43, PCMT1, GINM1 and LRP11 (also known as SORL1). The latter is a neuronal apolipoprotein E receptor important in pathogenesis of $\mathrm{AD}^{36}$.
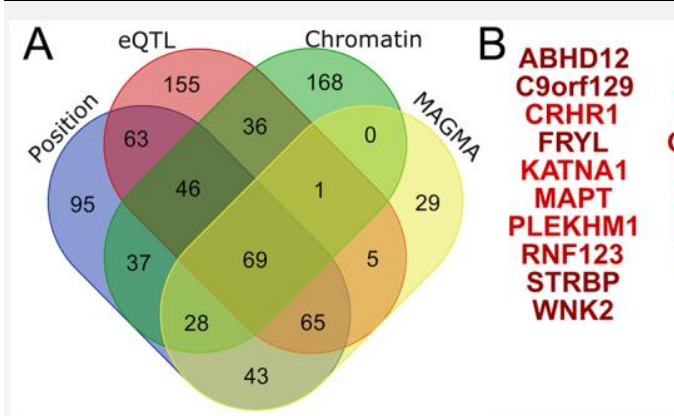

ACP2
CAMKV
CRTC2
GATAD2B
KBTBD4
MST1R
PLXNA2
RNFT2
SUFU
WNT3

\begin{tabular}{|c|c|c|c|c|}
\hline $\begin{array}{c}\text { ACTR1A } \\
\text { CCDC36 } \\
\text { DALRD3 } \\
\text { GINM1 } \\
\text { LATS1 } \\
\text { NICN1 } \\
\text { PRKAR2A } \\
\text { RREB1 } \\
\text { TCTA } \\
\text { ZBTB6 }\end{array}$ & $\begin{array}{c}\text { AFF1 } \\
\text { CELF1 } \\
\text { EFCAB5 } \\
\text { GMPPB } \\
\text { LEKR1 } \\
\text { NUP210L } \\
\text { QRICH1 } \\
\text { SEZ6 } \\
\text { TRIM8 } \\
\text { ZNF398 }\end{array}$ & $\begin{array}{c}\text { ARHGAP27 } \\
\text { CHSY1 } \\
\text { FAM172A } \\
\text { GNA12 } \\
\text { LEMD3 } \\
\text { NUP43 } \\
\text { RASL11B } \\
\text { SPPL2C } \\
\text { USP4 } \\
\text { ZNF425 }\end{array}$ & $\begin{array}{l}\text { ARL17B } \\
\text { COG4 } \\
\text { FAM53B } \\
\text { IP6K2 } \\
\text { LRP11 } \\
\text { P4HTM } \\
\text { RBM6 } \\
\text { SSH2 } \\
\text { VCAN } \\
\text { ZNF786 }\end{array}$ & $\begin{array}{c}\text { C12orf49 } \\
\text { CREB3L4 } \\
\text { FOXO3 } \\
\text { KANSL1 } \\
\text { LRRC37A } \\
\text { PCMT1 } \\
\text { RHOA } \\
\text { STH } \\
\text { WDR6 }\end{array}$ \\
\hline
\end{tabular}

133 Figure 2. Gene mapping of the $\mathbf{1 7 3}$ loci associated with the hippocampal formation implied $\mathbf{6 9}$ 134 genes by all mapping strategies. (A) Venn diagram showing number of genes mapped by the four 135 different strategies. (B) The 69 genes implied by all four strategies with color-coded P-values. 
medRxiv preprint doi: https://doi.org/10.1101/2021.08.18.21262223; this version posted August 24, 2021. The copyright holder for this preprint (which was not certified by peer review) is the author/funder, who has granted medRxiv a license to display the preprint in All rights reserved. No reuse allowed without permission.

Distributed genetic architecture across the hippocampal formation | Bahrami et al.

137 Genome-wide gene-based association studies (GWGAS; two-sided P $<2.752 \times 10^{-6}$ ) through MAGMA

138 identified 240 unique genes across the hippocampus (Supplementary Table 5). Many of the significant

139 gene sets reflected processes related to early development (Supplementary Table 7), such as

140 neurogenesis $\left(\mathrm{P}_{\mathrm{Bonf}}=6.8 \times 10^{-8}\right)$, regulation of anatomical structure morphogenesis $\left(\mathrm{P}_{\text {Bonf }}=1.0 \times 10^{-7}\right)$

141 and neuronal differentiation $\left(\mathrm{P}_{\mathrm{Bonf}}=5.0 \times 10^{-7}\right)$, potentially indicating that individual differences in

142 hippocampal volumes later in life may be largely determined early in development. Also, when focusing

143 on the 69 genes implicated from all four mapping strategies (see above), the gene-sets reflect processes

144 related to early development like regulation of cell morphogenesis $\left(\mathrm{P}=4.4 \times 10^{-6}\right.$ and $\left.\mathrm{P}=1.2 \times 10^{-5}\right)$

145 and axogenesis $\left(\mathrm{P}=2.3 \times 10^{-5}\right)$ but also to biological processes on reproduction, like multi organism

146 reproductive process $\left(\mathrm{P}=2.2 \times 10^{-5}\right)$, sexual reproduction $\left(\mathrm{P}=3.0 \times 10^{-5}\right)$ and gamete generation $(\mathrm{P}=$

$1475.0 \times 10^{-5}$ ), which might potentially represent a later hormonal modulation of hippocampal neurogenesis

148 (Supplementary Table 8). Although pathways important for neural differentiation are overrepresented

149 (Supplementary Table 9) we also found dominant pathways representing processes prominent during

150 the lifetime, like damage mechanisms (spinal cord injury and DNA damage response) and inflammation

151 (IL-5 signaling pathway, $I L-2$ signaling pathway and putative anti-inflammatory metabolites formation

152 from EPA) in addition to overrepresented pathways on vitamin B, D and E metabolism.

154 Genetic overlap between hippocampal formation and common brain disorders

155 Using major neurological and psychiatric disorders as proxies for potential age-dependent hippocampal

156 pathology, we studied the genetic overlap between hippocampal formation and eight disorders - ASD,

157 ADHD, SCZ, BIP, MIG, MD, PD and AD - with typical onset times across the lifespan. The commonly

158 used approach - genetic correlations of the disorders with individual hippocampus subregions - did not

159 show significant associations after Bonferroni correction for multiple comparisons (Supplementary

160 Table 10). However, conditional Q-Q plots ${ }^{37}$ conditioning the multivariate statistic of hippocampal

161 formation on the disorders and vice versa showed a clear pattern of pleiotropic enrichment in both

162 directions (Supplementary Figure 5). Conjunctional FDR analysis ${ }^{37,38}$ allowed us to test for shared

163 loci between the hippocampus and each of the disorders. Strikingly, we identified 7 loci significantly 
medRxiv preprint doi: https://doi.org/10.1101/2021.08.18.21262223; this version posted August 24, 2021. The copyright holder for this preprint (which was not certified by peer review) is the author/funder, who has granted medRxiv a license to display the preprint in All rights reserved. No reuse allowed without permission.

Distributed genetic architecture across the hippocampal formation | Bahrami et al.

164 (conjFDR <0.05) overlapping with ADHD, 4 loci with ASD, 63 with BIP, 130 with SCZ, 23 with MD,

16581 with MIG, 24 with $\mathrm{AD}$ and 13 loci significantly overlapping with PD (Figure 3A).

166
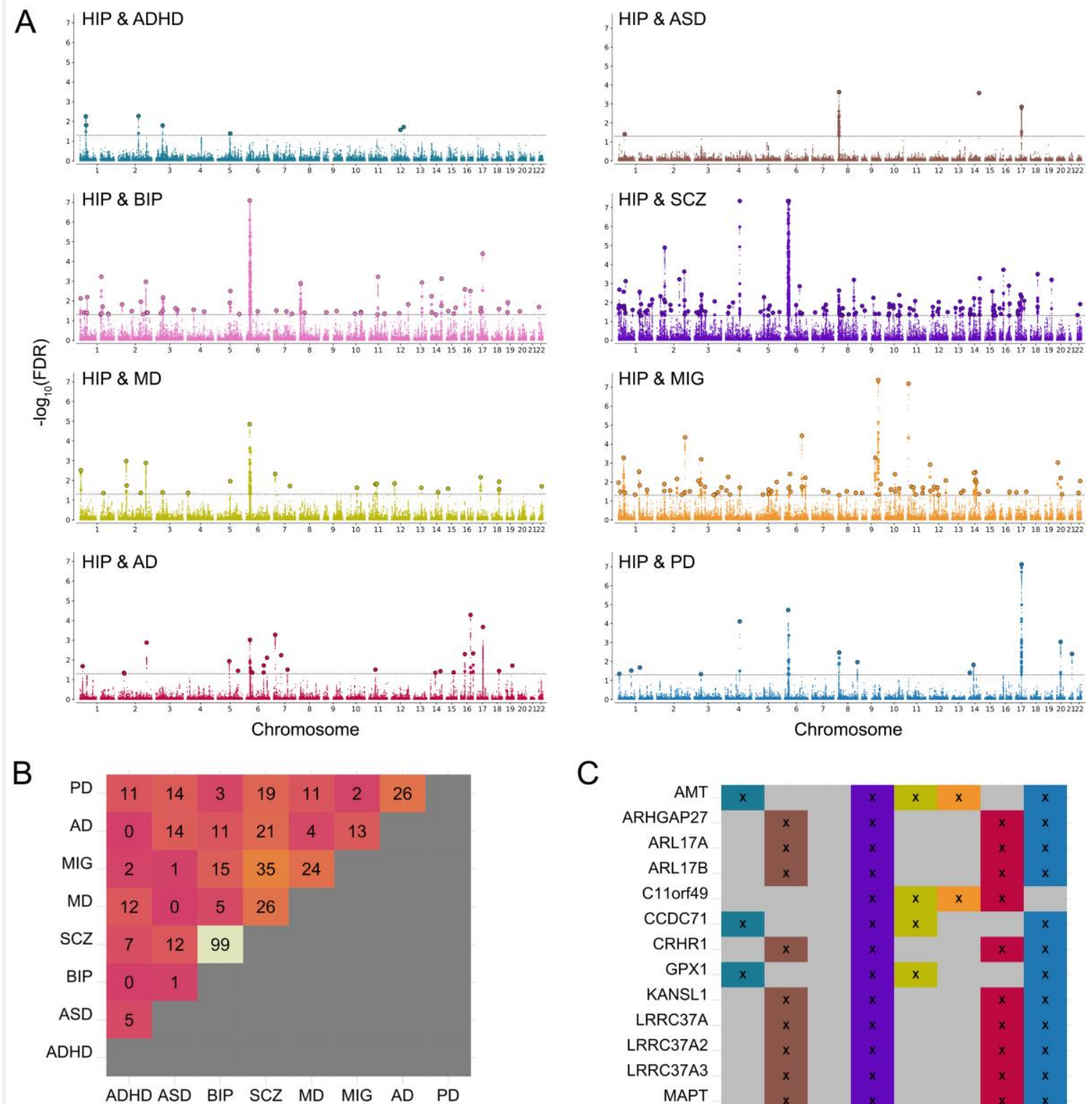

C

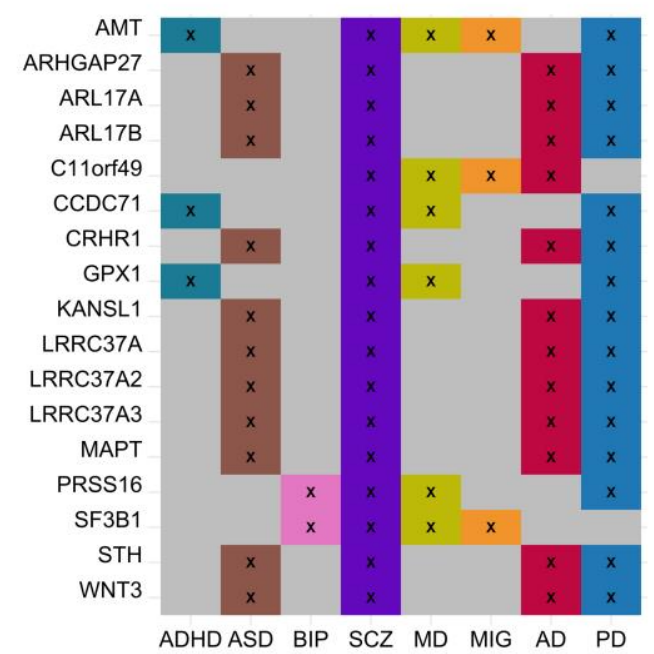

Number of overlapping genes

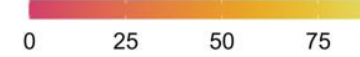

ADHD ASD BIP SCZ MD MIG AD PD

168 Figure 3. Genetic overlap between hippocampal formation and eight disorders with different onset times as proxies of age-dependent hippocampal pathology. (A) For each disorder, a

170 conjunctional FDR Manhattan plot is shown, illustrating the - $\log 10$ transformed conjunctional FDR

171 values for each SNP on the $\mathrm{y}$ axis and chromosomal positions along the $\mathrm{x}$ axis. The dotted horizontal

172 line represents the threshold for significant shared associations (conjFDR $<0.05)$. Independent lead

173 SNPs are encircled in black. (B) Various genes mapped from the conjunctional FDR analysis were 
medRxiv preprint doi: https://doi.org/10.1101/2021.08.18.21262223; this version posted August 24, 2021. The copyright holder for this preprint (which was not certified by peer review) is the author/funder, who has granted medRxiv a license to display the preprint in All rights reserved. No reuse allowed without permission.

Distributed genetic architecture across the hippocampal formation | Bahrami et al.

174

175

176

177

178

179

180

181

182

183

184

185

186

187

188

189

190

191

192

193

194

195

196

197

198

199

200

implied to overlap between hippocampal formation and multiple disorders. The figure illustrates the total number of genes implied in each combination of disorders. For example, 99 of the genes overlapping between hippocampal formation and SCZ were also found to overlap between hippocampal formation and BIP. (C) Panel C complements panel B with a list of genes that were implied for more than 3 disorders. One gene was mapped for five disorders (AMT) and 16 genes were mapped for four disorders. ASD autism spectrum disorder, ADHD attention deficit hyperactivity disorder, SCZ schizophrenia, BIP bipolar disorder, MIG migraine, MD, major depression, PD Parkinson's disease, AD Alzheimer's disease and HIP hippocampal formation.

82

83

Supplementary Tables 11-18 provide a full list of loci overlapping between hippocampal formation and the disorders. We mapped each of these loci to genes using positional, eQTL and chromatin state mapping (Supplementary Table 19) and checked for genes that were implicated for multiple disorders. By far strongest overlap was found between SCZ and BIP, where 99 of the genes overlapping between hippocampal formation and SCZ were also found to overlap between hippocampal formation and BIP (Figure 3B). While this overlap may be expected given the relatedness of the disorders, it is particularly noteworthy that we found large overlap between other combinations of disorders as well, some of which pertain very different onset times across the lifespan such as ASD and AD (14 genes), ADHD and PD (11 genes), or ASD and PD (14 genes). Many genes were implied for more than two disorders, and Figure 3C depicts the subset implicated as overlapping with hippocampal formation for at least four disorders. Again, it is particular worth noting the co-occurance for distinct disorders in different phases of life. For example, the most frequently mapped gene was the $A M T$ gene involved in glycinergic neurotransmission, found to overlap between hippocampal formation and ADHD, SCZ, MD, MIG and PD, respectively (Supplementary Table 19). Other examples are the tau protein associated genes MAPT and STH, found for ASD, SCZ, AD and PD, or the GPX1 gene, known to protect cells from oxidative stress and here found for ADHD, SCZ, MD and PD. This may illustrate genetic mechanisms independent of life phases and may suggest that some of the pleiotropy between brain disorders might be explained by shared mechanisms in hippocampal pathology. 
medRxiv preprint doi: https://doi.org/10.1101/2021.08.18.21262223; this version posted August 24, 2021. The copyright holder for this preprint (which was not certified by peer review) is the author/funder, who has granted medRxiv a license to display the preprint in All rights reserved. No reuse allowed without permission.

Distributed genetic architecture across the hippocampal formation | Bahrami et al.

\section{Discussion}

203 Taken together, our multivariate GWAS of the volumes of the hippocampal formation revealed a

204 plethora of genomic loci not identified in previous work, implicating a distributed nature of effects on

205 hippocampus. The mapped genes have roles in neurobiological processes across the lifespan.

206 Importantly, the profound overlap between hippocampal formation and common brain disorders and

207 the identification of some of the same genes implied for disorders with onset in different phases of life

208 suggests age-independent neuropathology and pinpoints potential disease-independent drug targets.

The distributed genetic architecture across the hippocampal formation, here revealed through

210173 hippocampus-associated loci and 69 genes mapped by four mapping strategies, pointed at pathways

211 with involvement across the lifespan, starting with embryogenic brain development, like axon guidance and neuronal migration, then involving neuronal plasticity processes including angiogenesis, and finally neurodegenerative processes such as DNA repair. We also found overrepresented pathways on vitamin

$214 \mathrm{~B}, \mathrm{D}$ and E metabolism, supporting their role in neuropathology ${ }^{39}$. Finally, the identified immune215 related pathways support that inflammatory responses could be involved in hippocampal pathology 216 mediating brain disease ${ }^{40-42}$.

217 Our results also suggest that several genes have a role in hippocampal pathology across multiple

218 brain disorders, with onset times ranging across the lifespan. These findings not only support the notion 219 of pleiotropy across a spectrum of neurological and psychiatric disorders but may also pinpoint to both, 220 age- and disorder-independent drug targets. For example, our discovery of the AMT gene overlapping 221 between hippocampal formation and ADHD, SCZ, MD, MIG and PD, respectively, may implicate an 222 age-independent role of glycine in hippocampal pathology. The AMT gene codes for 223 aminomethyltransferase (T-protein), an enzyme crucial for the glycine decarboxylase complex (GCS)

224 in mitochondria. Glycine is a primary inhibitory neurotransmitter in the spinal cord and brainstem, but increasing evidence show important glycine involvement also in the hippocampal formation ${ }^{43,44}$.

226 Glycine exerts a tonic inhibitory role through extrasynaptic glycine receptor chloride channels ${ }^{45}$, in 227 addition to modulation of NMDA receptors in the hippocampal formation ${ }^{46,47}$. Through regulation of 228 both glycine and serine synthesis and cleavage, aminomethyltransferase as part of the glycine 
medRxiv preprint doi: https://doi.org/10.1101/2021.08.18.21262223; this version posted August 24, 2021. The copyright holder for this preprint (which was not certified by peer review) is the author/funder, who has granted medRxiv a license to display the preprint in All rights reserved. No reuse allowed without permission.

Distributed genetic architecture across the hippocampal formation | Bahrami et al.

decarboxylase complex, may provide a homeostatic regulation of hippocampal function and plasticity

230 by simultaneous activation of excitatory NMDA receptors and inhibitory glycine receptors ${ }^{43,48}$. The

231 glycine site on the NMDA receptors is currently under investigation as a promising drug target for

232 several of the disorders that we here associated with the $A M T$ gene, including $\mathrm{ADHD}^{49,50}, \mathrm{PD}^{51}, \mathrm{SCZ}^{52}$

233 and $\mathrm{MD}^{53}$, either by direct glycine supplementation, other substances working on the same receptor site

234 or by increasing endogenous glycine by inhibiting the glycine transporter. Another example for a

235 potential age- and disorder-independent drug target is the microtubule-associated protein tau (MAPT)

236 gene, which was here implicated for ASD, SCZ, AD and PD. Indeed, tau has for long been a marker of

$237 \mathrm{AD}$ and $\mathrm{PD}^{54}$ yet has recently also gained focus for $\mathrm{ASD}^{55}$, with animal models suggesting that tau

238 reduction may prevent behavioural signs of this neurodevelopmental disorder ${ }^{56}$. Taken together, our

239 results therefore add support for disorder-independent gene targets for hippocampal pathology across

240 the lifespan, including $A M T$ and $M A P T$, among others, and illustrate how the multivariate GWAS

241 approach can reveal overlapping biochemical mechanisms underlying different disorders and traits.

In conclusion, our results suggest a polygenic architecture of the hippocampal formation,

distributed across its subregions. The genetic overlap with various developmental and degenerative

244 brain disorders implicated genes that may be relevant targets for future studies into the mechanisms

underlying hippocampal functioning and pathology across the lifespan. With several of the findings

fitting currently studied treatment targets (e.g. the glycine site on the NMDA receptor), our results also

confirm the utility of the approach and suggest that capitalizing on the distributed nature of genetic effects on the brain will be instrumental in our future endeavours to further understand mechanisms underlying the brain and its disorders.

\section{Acknowledgments}

The authors were funded by the Research Council of Norway (TK: 276082. OAA: 213837, 223273, 248778, 273291, 262656, 229129, 283798, 311993. LTW: 204966, 249795, 273345), the South-Eastern 
medRxiv preprint doi: https://doi.org/10.1101/2021.08.18.21262223; this version posted August 24, 2021. The copyright holder for this preprint (which was not certified by peer review) is the author/funder, who has granted medRxiv a license to display the preprint in All rights reserved. No reuse allowed without permission.

Distributed genetic architecture across the hippocampal formation | Bahrami et al.

European Research Council (LTW: ERCStG 802998), and an NVIDIA Corporation GPU Grant (TK).

257 The funding bodies had no role in the analysis or interpretation of the data; the preparation, review or 258 approval of the manuscript; nor in the decision to submit the manuscript for publication. This work was 259 performed on the TSD (Tjeneste for Sensitive Data) facilities, owned by the University of Oslo, 260 operated and developed by the TSD service group at the University of Oslo, IT-Department 261 (USIT) and on resources provided by UNINETT Sigma2 - the National Infrastructure for High

262 Performance Computing and Data Storage in Norway. The research has been conducted using the UK

263 Biobank Resource (access code 27412) and using summary statistics for various brain disorders that 264 partly included 23andMe data. We would like to thank the research participants and employees of UK Biobank, the 23andMe and the consortia contributing summary statistics for making this work possible.

\section{Author contributions}

SB and TK conceived the study and analysed the data. KN and TK interpreted the results and spearheaded the writing. SB and TK drafted the online methods. All authors gave conceptual input on the methods and/or results and all authors contributed to and approved the final manuscript.

\section{Competing interests}

273 OAA has received speaker's honorarium from Lundbeck and Sunovion, and is a consultant to

274 HealthLytix. A.M.D. is a Founder of and holds equity in CorTechs Labs, Inc, and serves on its

275 Scientific Advisory Board. The terms of this arrangement have been reviewed and approved by UCSD in accordance with its conflict of interest policies. Other authors report no conflicts.

\section{References} episodic memory. Neuron 35, 625-641, doi:10.1016/s0896-6273(02)00830-9 (2002). 
medRxiv preprint doi: https://doi.org/10.1101/2021.08.18.21262223; this version posted August 24, 2021. The copyright holder for this preprint (which was not certified by peer review) is the author/funder, who has granted medRxiv a license to display the preprint in All rights reserved. No reuse allowed without permission.

Distributed genetic architecture across the hippocampal formation | Bahrami et al.

2832 Eichenbaum, H. A cortical-hippocampal system for declarative memory. Nat Rev Neurosci 1, 41-50, doi:10.1038/35036213 (2000).

3 Epstein, R. A., Patai, E. Z., Julian, J. B. \& Spiers, H. J. The cognitive map in humans: spatial navigation and beyond. Nat Neurosci 20, 1504-1513, doi:10.1038/nn.4656 (2017).

4 Maguire, E. A. et al. Navigation-related structural change in the hippocampi of taxi drivers. Proc Natl Acad Sci U S A 97, 4398-4403, doi:10.1073/pnas.070039597 (2000).

Bannerman, D. M. et al. Hippocampal synaptic plasticity, spatial memory and anxiety. Nat Rev Neurosci 15, 181-192, doi:10.1038/nrn3677 (2014). Chudasama, Y., Wright, K. S. \& Murray, E. A. Hippocampal lesions in rhesus monkeys disrupt emotional responses but not reinforcer devaluation effects. Biol Psychiatry 63, 1084-1091, doi:10.1016/j.biopsych.2007.11.012 (2008). Scoville, W. B. \& Milner, B. Loss of recent memory after bilateral hippocampal lesions. J Neurol Neurosurg Psychiatry 20, 11-21, doi:10.1136/jnnp.20.1.11 (1957).

8 Iglesias, J. E. et al. A computational atlas of the hippocampal formation using ex vivo, ultra-high resolution MRI: Application to adaptive segmentation of in vivo MRI. Neuroimage 115, 117-137, doi:10.1016/j.neuroimage.2015.04.042 (2015). Eriksson, P. S. et al. Neurogenesis in the adult human hippocampus. Nat Med 4, 1313-1317, doi:10.1038/3305 (1998).

10 Sahay, A. \& Hen, R. Adult hippocampal neurogenesis in depression. Nat Neurosci 10, 1110-1115, doi:10.1038/nn1969 (2007).

11 Kaufmann, T. et al. Common brain disorders are associated with heritable patterns of apparent aging of the brain. Nat Neurosci 22, 1617-1623, doi:10.1038/s41593-0190471-7 (2019). Marin, O. Developmental timing and critical windows for the treatment of psychiatric disorders. Nat Med 22, 1229-1238, doi:10.1038/nm.4225 (2016). pathway: the weak link in psychiatric disorders? Eur Neuropsychopharmacol 23, 1165-1181, doi:10.1016/j.euroneuro.2012.10.018 (2013).

Eastwood, S. L. \& Harrison, P. J. Hippocampal synaptic pathology in schizophrenia,
bipolar disorder and major depression: a study of complexin mRNAs. Mol Psychiatry Heckers, S. et al. Impaired recruitment of the hippocampus during conscious recollection in schizophrenia. Nat Neurosci 1, 318-323, doi:10.1038/1137 (1998). 5, 425-432, doi:10.1038/sj.mp.4000741 (2000).

16 Borsook, D., Maleki, N., Becerra, L. \& McEwen, B. Understanding migraine through the lens of maladaptive stress responses: a model disease of allostatic load. Neuron 73, 219-234, doi:10.1016/j.neuron.2012.01.001 (2012).

17 MacQueen, G. M. et al. Course of illness, hippocampal function, and hippocampal volume in major depression. Proc Natl Acad Sci U S A 100, 1387-1392, doi:10.1073/pnas.0337481100 (2003).

18 Calabresi, P., Castrioto, A., Di Filippo, M. \& Picconi, B. New experimental and clinical links between the hippocampus and the dopaminergic system in Parkinson's disease. Lancet Neurol 12, 811-821, doi:10.1016/S1474-4422(13)70118-2 (2013).

19 Masters, C. L. et al. Alzheimer's disease. Nat Rev Dis Primers 1, 15056, doi:10.1038/nrdp.2015.56 (2015).

20 Barnes, J. et al. A meta-analysis of hippocampal atrophy rates in Alzheimer's disease. Neurobiol Aging 30, 1711-1723, doi:10.1016/j.neurobiolaging.2008.01.010 (2009).

21 Thompson, C. L. et al. Genomic anatomy of the hippocampus. Neuron 60, 10101021, doi:10.1016/j.neuron.2008.12.008 (2008). 
medRxiv preprint doi: https://doi.org/10.1101/2021.08.18.21262223; this version posted August 24, 2021. The copyright holder for this preprint (which was not certified by peer review) is the author/funder, who has granted medRxiv a license to display the preprint in All rights reserved. No reuse allowed without permission.

Distributed genetic architecture across the hippocampal formation | Bahrami et al.

333

334

335

336

337

338

339

340

341

342

343

344

345

346

347

348

349

350

351

352

353

354

355

356

357

358

359

360

361

362

363

364

365

366

367

368

369

370

371

372

373

374

375

376

377

378

379

380

381

22 Hibar, D. P. et al. Novel genetic loci associated with hippocampal volume. Nat Commun 8, 13624, doi:10.1038/ncomms13624 (2017).

23 Stein, J. L. et al. Identification of common variants associated with human hippocampal and intracranial volumes. Nat Genet 44, 552-561, doi:10.1038/ng.2250 (2012).

24 van der Meer, D. et al. Brain scans from 21,297 individuals reveal the genetic architecture of hippocampal subfield volumes. Mol Psychiatry 25, 3053-3065, doi:10.1038/s41380-018-0262-7 (2020).

25 Vilor-Tejedor, N. et al. Genetic Influences on Hippocampal Subfields: An Emerging Area of Neuroscience Research. Neurol Genet 7, e591, doi:10.1212/NXG.0000000000000591 (2021).

26 van der Meer, D. et al. Understanding the genetic determinants of the brain with MOSTest. Nat Commun 11, 3512, doi:10.1038/s41467-020-17368-1 (2020).

27 van der Meer, D. et al. The genetic architecture of human cortical folding. bioRxiv, 2021.2001.2013.426555, doi:10.1101/2021.01.13.426555 (2021).

28 Roelfs, D. et al. Genetic overlap between multivariate measures of human functional brain connectivity and psychiatric disorders. medRxiv, 2021.2006.2015.21258954, doi:10.1101/2021.06.15.21258954 (2021).

29 Bycroft, C. et al. The UK Biobank resource with deep phenotyping and genomic data. Nature 562, 203-209, doi:10.1038/s41586-018-0579-z (2018).

30 Watanabe, K., Taskesen, E., van Bochoven, A. \& Posthuma, D. Functional mapping and annotation of genetic associations with FUMA. Nat Commun 8, 1826, doi:10.1038/s41467-017-01261-5 (2017).

31 Boyle, A. P. et al. Annotation of functional variation in personal genomes using RegulomeDB. Genome Res 22, 1790-1797, doi:10.1101/gr.137323.112 (2012).

32 Roadmap Epigenomics, C. et al. Integrative analysis of 111 reference human epigenomes. Nature 518, 317-330, doi:10.1038/nature14248 (2015).

33 Hellemans, J. et al. Loss-of-function mutations in LEMD3 result in osteopoikilosis, Buschke-Ollendorff syndrome and melorheostosis. Nat Genet 36, 1213-1218, doi:10.1038/ng1453 (2004).

34 Tong, Y. et al. The RNFT2/IL-3Ralpha axis regulates IL-3 signaling and innate immunity. JCI Insight 5, doi:10.1172/jci.insight.133652 (2020).

35 Thermes, V. et al. Medaka simplet (FAM53B) belongs to a family of novel vertebrate genes controlling cell proliferation. Development 133, 1881-1890, doi:10.1242/dev.02350 (2006).

36 Cuccaro, M. L. et al. SORL1 mutations in early- and late-onset Alzheimer disease. Neurol Genet 2, e116, doi:10.1212/NXG.0000000000000116 (2016).

37 Andreassen, O. A. et al. Improved detection of common variants associated with schizophrenia and bipolar disorder using pleiotropy-informed conditional false discovery rate. PLoS Genet 9, e1003455, doi:10.1371/journal.pgen.1003455 (2013).

38 Smeland, O. B. et al. Discovery of shared genomic loci using the conditional false discovery rate approach. Hum Genet 139, 85-94, doi:10.1007/s00439-019-02060-2 (2020).

39 Eyles, D. W., Burne, T. H. \& McGrath, J. J. Vitamin D, effects on brain development, adult brain function and the links between low levels of vitamin $\mathrm{D}$ and neuropsychiatric disease. Front Neuroendocrinol 34, 47-64, doi:10.1016/j.yfrne.2012.07.001 (2013).

40 Edvinsson, L., Haanes, K. A. \& Warfvinge, K. Does inflammation have a role in migraine? Nat Rev Neurol 15, 483-490, doi:10.1038/s41582-019-0216-y (2019). 
medRxiv preprint doi: https://doi.org/10.1101/2021.08.18.21262223; this version posted August 24, 2021. The copyright holder for this preprint (which was not certified by peer review) is the author/funder, who has granted medRxiv a license to display the preprint in All rights reserved. No reuse allowed without permission.

Distributed genetic architecture across the hippocampal formation | Bahrami et al.

382

383

384

385

386

387

388

389

390

391

392

393

394

395

396

397

398

399

400

401

402

403

404

405

406

407

408

409

410

411

412

413

414

415

416

417

418

419

420

421

422

423

424

41 Nordengen, K. et al. Glial activation and inflammation along the Alzheimer's disease continuum. J Neuroinflammation 16, 46, doi:10.1186/s12974-019-1399-2 (2019).

42 Yuan, N., Chen, Y., Xia, Y., Dai, J. \& Liu, C. Inflammation-related biomarkers in major psychiatric disorders: a cross-disorder assessment of reproducibility and specificity in 43 meta-analyses. Transl Psychiatry 9, 233, doi:10.1038/s41398-0190570-y (2019).

43 Keck, T., Lillis, K. P., Zhou, Y. D. \& White, J. A. Frequency-dependent glycinergic inhibition modulates plasticity in hippocampus. J Neurosci 28, 7359-7369, doi:10.1523/JNEUROSCI.5618-07.2008 (2008).

44 Keck, T. \& White, J. A. Glycinergic inhibition in the hippocampus. Rev Neurosci 20, 13-22, doi:10.1515/revneuro.2009.20.1.13 (2009).

45 Zhang, L. H., Gong, N., Fei, D., Xu, L. \& Xu, T. L. Glycine uptake regulates hippocampal network activity via glycine receptor-mediated tonic inhibition. Neuropsychopharmacology 33, 701-711, doi:10.1038/sj.npp.1301449 (2008).

46 Johnson, J. W. \& Ascher, P. Glycine potentiates the NMDA response in cultured mouse brain neurons. Nature 325, 529-531, doi:10.1038/325529a0 (1987).

47 Nong, Y. et al. Glycine binding primes NMDA receptor internalization. Nature 422, 302-307, doi:10.1038/nature01497 (2003).

48 Liu, L. et al. Role of NMDA receptor subtypes in governing the direction of hippocampal synaptic plasticity. Science 304, 1021-1024, doi:10.1126/science.1096615 (2004).

49 Hegvik, T. A. et al. Druggable genome in attention deficit/hyperactivity disorder and its co-morbid conditions. New avenues for treatment. Mol Psychiatry, doi:10.1038/s41380-019-0540-z (2019).

$50 \quad$ ClincalTrial. Sublingual Glycine vs. Placebo on Attentional Difficulties and Hyperactivity in Prepuberal Children, <https://ClinicalTrials.gov/show/NCT02655276> (Completed).

51 Heresco-Levy, U., Shoham, S. \& Javitt, D. C. Glycine site agonists of the N-methylD-aspartate receptor and Parkinson's disease: a hypothesis. Mov Disord 28, 419-424, doi:10.1002/mds.25306 (2013).

52 Heresco-Levy, U. et al. Efficacy of high-dose glycine in the treatment of enduring negative symptoms of schizophrenia. Arch Gen Psychiatry 56, 29-36, doi:10.1001/archpsyc.56.1.29 (1999).

53 Huang, C. C. et al. Inhibition of glycine transporter-I as a novel mechanism for the treatment of depression. Biol Psychiatry 74, 734-741, doi:10.1016/j.biopsych.2013.02.020 (2013).

54 Zhang, X. et al. Tau Pathology in Parkinson's Disease. Front Neurol 9, 809, doi:10.3389/fneur.2018.00809 (2018).

55 Grigg, I. et al. Tauopathy in the young autistic brain: novel biomarker and therapeutic target. Transl Psychiatry 10, 228, doi:10.1038/s41398-020-00904-4 (2020).

56 Tai, C. et al. Tau Reduction Prevents Key Features of Autism in Mouse Models. Neuron 106, 421-437 e411, doi:10.1016/j.neuron.2020.01.038 (2020). 
medRxiv preprint doi: https://doi.org/10.1101/2021.08.18.21262223; this version posted August 24, 2021. The copyright holder for this preprint (which was not certified by peer review) is the author/funder, who has granted medRxiv a license to display the preprint in All rights reserved. No reuse allowed without permission.

\section{Online Methods}

Sample and pre-processing of imaging and genetic data

The UK Biobank was approved by the National Health Service National Research Ethics Service (ref. range: 45 - 81, mean: 62.9 , sd: 7.6 years, $53.6 \%$ females) for the replication in independent data. removed SNPs with an imputation quality score $<0.5$, a minor allele frequency $<0.05$, missing in more than 5\% of individuals, and failing the Hardy Weinberg equilibrium tests at a $P<1 \mathrm{e}-6$.

\section{Multivariate genome-wide association analysis}

For each of the 19 regions of the hippocampal formation - parasubiculum, presubiculum head and body, subiculum head and body, CA1/CA3/CA4 head and body, GC-ML-DG head and body, molecular layer head and body, HATA, fimbria, hippocampal tail, hippocampal fissure - as well as for total hippocampus volume we calculated the average volume between the left and right hemisphere and subsequently residualized the volumes for age, age squared, sex, scanning site, Euler number as a proxy of image quality, intracranial volume and the first 20 genetic principal components. The resulting residuals for the 20 regions were jointly fed into MOSTest ${ }^{26}$ analysis, yielding a multivariate GWAS summary statistic across all 20 features. For comparison to state-of-the art univariate approaches, we also performed univariate GWAS (extracted from the univariate stream of MOSTest ${ }^{26}$ ). Supplemental genetic correlation analyses were performed using LD-score regression ${ }^{58,59}$. 
medRxiv preprint doi: https://doi.org/10.1101/2021.08.18.21262223; this version posted August 24, 2021. The copyright holder for this preprint (which was not certified by peer review) is the author/funder, who has granted medRxiv a license to display the preprint in All rights reserved. No reuse allowed without permission.

Distributed genetic architecture across the hippocampal formation | Bahrami et al.

451

452

453

454

455

456

457

458

459

460

461

462

463

464

465

466

467

468

469

470

471

472

473

474

475

476

statistical significance threshold $P<5 \mathrm{e}-8$. All SNPs at $\mathrm{r}^{2}<0.6$ with each other were considered as independent significant SNPs and a fraction of the independent significant SNPs in approximate linkage equilibrium with each other at $\mathrm{r}^{2}<0.1$ were considered as lead SNPs. Post-GWAS eQTL analysis was also performed using FUMA. The full FUMA analysis including the corresponding parameter file will be made available through https://fuma.ctglab.nl/browse upon acceptance.

Genetic overlap between hippocampal formation and major brain disorders

We accessed GWAS summary statistics for migraine (MIG) from International headache genetics Consortium $^{60}$ and for Parkinson's disease (PD) from the International Parkinson Disease Genomics Consortium $^{61,62}$. The latter included 23andMe data. 23andMe participants provided informed consent and participated in the research online, under a protocol approved by the external AAHRPP-accredited IRB, Ethical \& Independent Review Services (E\&I Review). Furthermore, from the Psychiatric Genomics Consortium we accessed summary statistics for attention deficit hyperactivity disorder $(\mathrm{ADHD})^{63}$, autism spectrum disorder (ASD $)^{64}$, bipolar disorder (BIP $)^{65}$ and major depression (MD) ${ }^{66}$. Finally, we included data from recent studies of schizophrenia $(\mathrm{SCZ})^{67}$ and of Alzheimer's disease $(\mathrm{AD})^{68}$

Using conjunctional FDR statistics $(\text { FDR }<0.05)^{37,38}$, we identified shared variants associated with hippocampal formation and each of the above-mentioned brain disorders. Two genomic regions, the extended major histocompatibility complex genes region (hg19 location Chr 6: 2511910633854733) and chromosome 8p23.1 (hg19 location Chr 8: 7242715-12483982) for all cases and MAPT region for $\mathrm{PD}$ and $A P O E$ region for $\mathrm{AD}$ and $\mathrm{ASD}$, respectively were excluded from the FDR fitting procedures because complex correlations in regions with intricate LD can bias FDR estimation.

We submitted the results from conjunctional FDR to FUMA v1.3.6 $6^{30}$ to annotate the genomic loci with conjFDR value $<0.10$ having an $\mathrm{r} 2 \geq 0.6$ with one of the independent significant SNPs. FUMA annotates associated SNPs based on functional Categories, Combined Annotation Dependent Depletion (CADD) scores which predicts the deleteriousness of SNPs on protein structure/function ${ }^{69}$, 
medRxiv preprint doi: https://doi.org/10.1101/2021.08.18.21262223; this version posted August 24, 2021. The copyright holder for this preprint (which was not certified by peer review) is the author/funder, who has granted medRxiv a license to display the preprint in All rights reserved. No reuse allowed without permission.

Distributed genetic architecture across the hippocampal formation | Bahrami et al.

477 RegulomeDB scores which predicts regulatory functions ${ }^{31}$; and chromatin states that shows the 478 transcription/regulation effects of chromatin states at the SNP locus ${ }^{70}$. We also conducted Gene 479 Ontology gene-set analyses based on FUMA's gene ontology classification system ${ }^{30}$ and pathway 480 analyses $^{71}$ for the all mapped genes and the 69 common mapped genes of hippocampal formation.

Data availability

483 In this study we used brain imaging and genetics data from the UK Biobank 484 [https://www.ukbiobank.ac.uk/], and GWAS summary statistics obtained from the Psychiatric 485 Genomics Consortium [https://www.med.unc.edu/pgc/], 23andMe [https://www.23andme.com/], 486 International headache genetics Consortium (IHGC) [http://www.headachegenetics.org], the 487 International Genomics of Alzheimer's Project [http://web.pasteur-

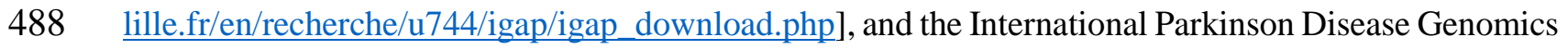

489 Consortium [https://pdgenetics.org/]. The latter included 23andMe data, which was made available 490 through 23andMe under an agreement with 23andMe that protects the privacy of the 23andMe 491 participants [https://research.23andme.com/collaborate/\#dataset-access/]. our github repository [https://github.com/norment/open-science] upon acceptance of the manuscript for

494 publication. Likewise, we will publish the FUMA results on the FUMA website 495 [https://fuma.ctglab.nl/browse/] upon acceptance.

498 All code and software needed to generate the results is available as part of public resources, specifically 499 MOSTest (https://github.com/precimed/mostest), FUMA (https://fuma.ctglab.nl/), conjunctional FDR 500 (https://github.com/precimed/pleiofdr/) and LD score regression (https://github.com/bulik/ldsc). 
medRxiv preprint doi: https://doi.org/10.1101/2021.08.18.21262223; this version posted August 24, 2021. The copyright holder for this preprint (which was not certified by peer review) is the author/funder, who has granted medRxiv a license to display the preprint in All rights reserved. No reuse allowed without permission.

Distributed genetic architecture across the hippocampal formation | Bahrami et al.

\section{References of the Online Methods}

5038 Iglesias, J. E. et al. A computational atlas of the hippocampal formation using ex vivo, ultra-high resolution MRI: Application to adaptive segmentation of in vivo MRI. Neuroimage 115, 117-137, doi:10.1016/j.neuroimage.2015.04.042 (2015).

26 van der Meer, D. et al. Understanding the genetic determinants of the brain with MOSTest. Nat Commun 11, 3512, doi:10.1038/s41467-020-17368-1 (2020).

29 Bycroft, C. et al. The UK Biobank resource with deep phenotyping and genomic data. Nature 562, 203-209, doi:10.1038/s41586-018-0579-z (2018). and annotation of genetic associations with FUMA. Nat Commun 8, 1826, doi:10.1038/s41467-017-01261-5 (2017).

31 Boyle, A. P. et al. Annotation of functional variation in personal genomes using RegulomeDB. Genome Res 22, 1790-1797, doi:10.1101/gr.137323.112 (2012).

37 Andreassen, O. A. et al. Improved detection of common variants associated with schizophrenia and bipolar disorder using pleiotropy-informed conditional false discovery rate. PLoS Genet 9, e1003455, doi:10.1371/journal.pgen.1003455 (2013).

38 Smeland, O. B. et al. Discovery of shared genomic loci using the conditional false discovery rate approach. Hum Genet 139, 85-94, doi:10.1007/s00439-019-02060-2 (2020).

57 Fischl, B. et al. Whole brain segmentation: automated labeling of neuroanatomical structures in the human brain. Neuron 33, 341-355, doi:10.1016/s08966273(02)00569-x (2002).

58 Bulik-Sullivan, B. et al. An atlas of genetic correlations across human diseases and traits. Nat Genet 47, 1236-1241, doi:10.1038/ng.3406 (2015).

59 Bulik-Sullivan, B. K. et al. LD Score regression distinguishes confounding from polygenicity in genome-wide association studies. Nat Genet 47, 291-295, doi:10.1038/ng.3211 (2015).

60 Gormley, P. et al. Meta-analysis of 375,000 individuals identifies 38 susceptibility loci for migraine. Nat Genet 48, 856-866, doi:10.1038/ng.3598 (2016).

61 Nalls, M. A. et al. Large-scale meta-analysis of genome-wide association data identifies six new risk loci for Parkinson's disease. Nat Genet 46, 989-993, doi:10.1038/ng.3043 (2014).

62 Chang, D. et al. A meta-analysis of genome-wide association studies identifies 17 new Parkinson's disease risk loci. Nat Genet 49, 1511-1516, doi:10.1038/ng.3955 (2017).

63 Demontis, D. et al. Discovery of the first genome-wide significant risk loci for attention deficit/hyperactivity disorder. Nat Genet 51, 63-75, doi:10.1038/s41588018-0269-7 (2019).

64 Grove, J. et al. Identification of common genetic risk variants for autism spectrum disorder. Nat Genet 51, 431-444, doi:10.1038/s41588-019-0344-8 (2019).

65 Mullins, N. et al. Genome-wide association study of more than 40,000 bipolar disorder cases provides new insights into the underlying biology. Nat Genet 53, 817829, doi:10.1038/s41588-021-00857-4 (2021).

66 Wray, N. R. et al. Genome-wide association analyses identify 44 risk variants and refine the genetic architecture of major depression. Nat Genet 50, 668-681, doi:10.1038/s41588-018-0090-3 (2018).

67 Pardinas, A. F. et al. Common schizophrenia alleles are enriched in mutationintolerant genes and in regions under strong background selection. Nat Genet 50, 381389, doi:10.1038/s41588-018-0059-2 (2018). 
medRxiv preprint doi: https://doi.org/10.1101/2021.08.18.21262223; this version posted August 24, 2021. The copyright holder for this preprint (which was not certified by peer review) is the author/funder, who has granted medRxiv a license to display the preprint in All rights reserved. No reuse allowed without permission.

Distributed genetic architecture across the hippocampal formation | Bahrami et al. Implicates Microglia and Immune Cells. medRxiv, 2020.2011.2020.20235275, doi:10.1101/2020.11.20.20235275 (2020). Kircher, M. et al. A general framework for estimating the relative pathogenicity of human genetic variants. Nat Genet 46, 310-315, doi:10.1038/ng.2892 (2014). Zhu, Z. et al. Integration of summary data from GWAS and eQTL studies predicts complex trait gene targets. Nat Genet 48, 481-487, doi:10.1038/ng.3538 (2016). Kamburov, A., Wierling, C., Lehrach, H. \& Herwig, R. ConsensusPathDB--a database for integrating human functional interaction networks. Nucleic Acids Res 37, D623-628, doi:10.1093/nar/gkn698 (2009). 
medRxiv preprint doi: https://doi.org/10.1101/2021.08.18.21262223; this version posted August 24, 2021. The copyright holder for this preprint (which was not certified by peer review) is the author/funder, who has granted medRxiv a license to display the preprint in All rights reserved. No reuse allowed without permission.

\section{Supplementary Figures}

563

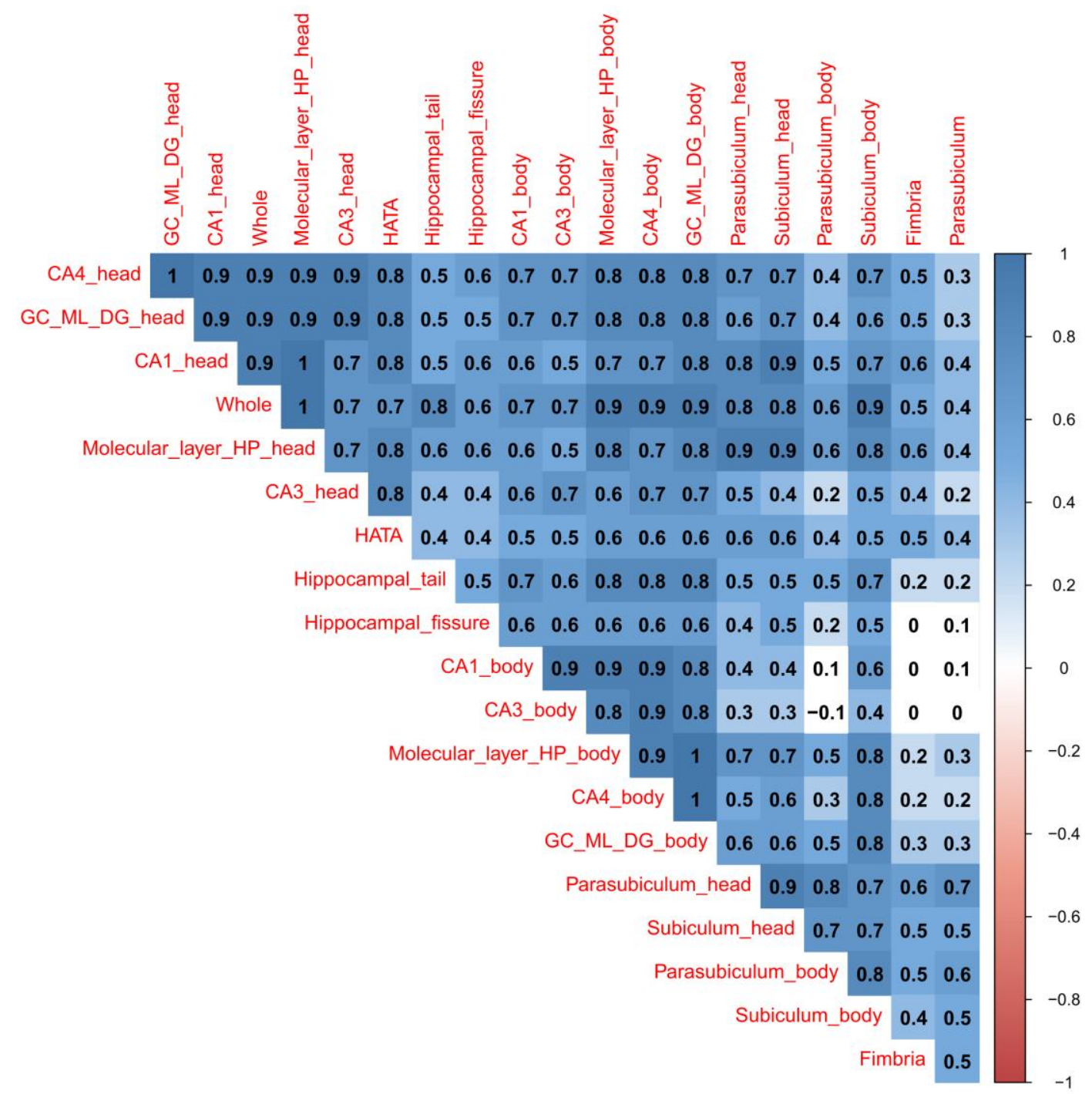

566 Supplementary Figure 1. Genetic correlations between hippocampus volumes. For each pair of regions, the LD-score regression based genetic correlations of the univariate summary statistics are

568 presented. 
medRxiv preprint doi: https://doi.org/10.1101/2021.08.18.21262223; this version posted August 24, 2021. The copyright holder for this preprint (which was not certified by peer review) is the author/funder, who has granted medRxiv a license to display the preprint in All rights reserved. No reuse allowed without permission.

Distributed genetic architecture across the hippocampal formation | Bahrami et al.
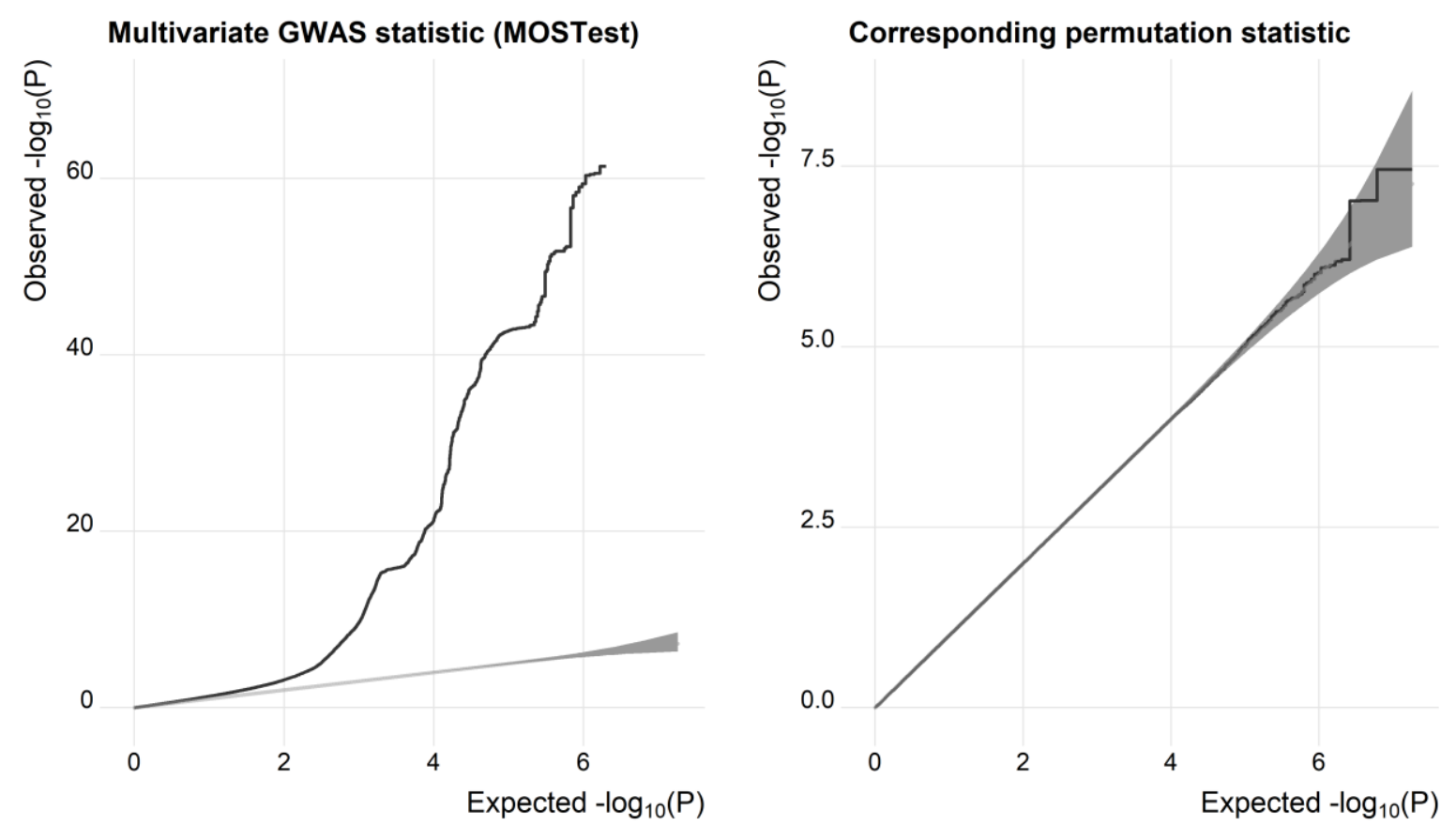

Supplementary Figure 2. Quantile-quantile plots from MOSTest analysis. The left panel depicts signal from MOSTest analysis. The right panel shows test statistics under null (from permutation testing) and confirms validity of the MOSTest test statistics. 
medRxiv preprint doi: https://doi.org/10.1101/2021.08.18.21262223; this version posted August 24, 2021. The copyright holder for this preprint (which was not certified by peer review) is the author/funder, who has granted medRxiv a license to display the preprint in All rights reserved. No reuse allowed without permission.

Distributed genetic architecture across the hippocampal formation | Bahrami et al.
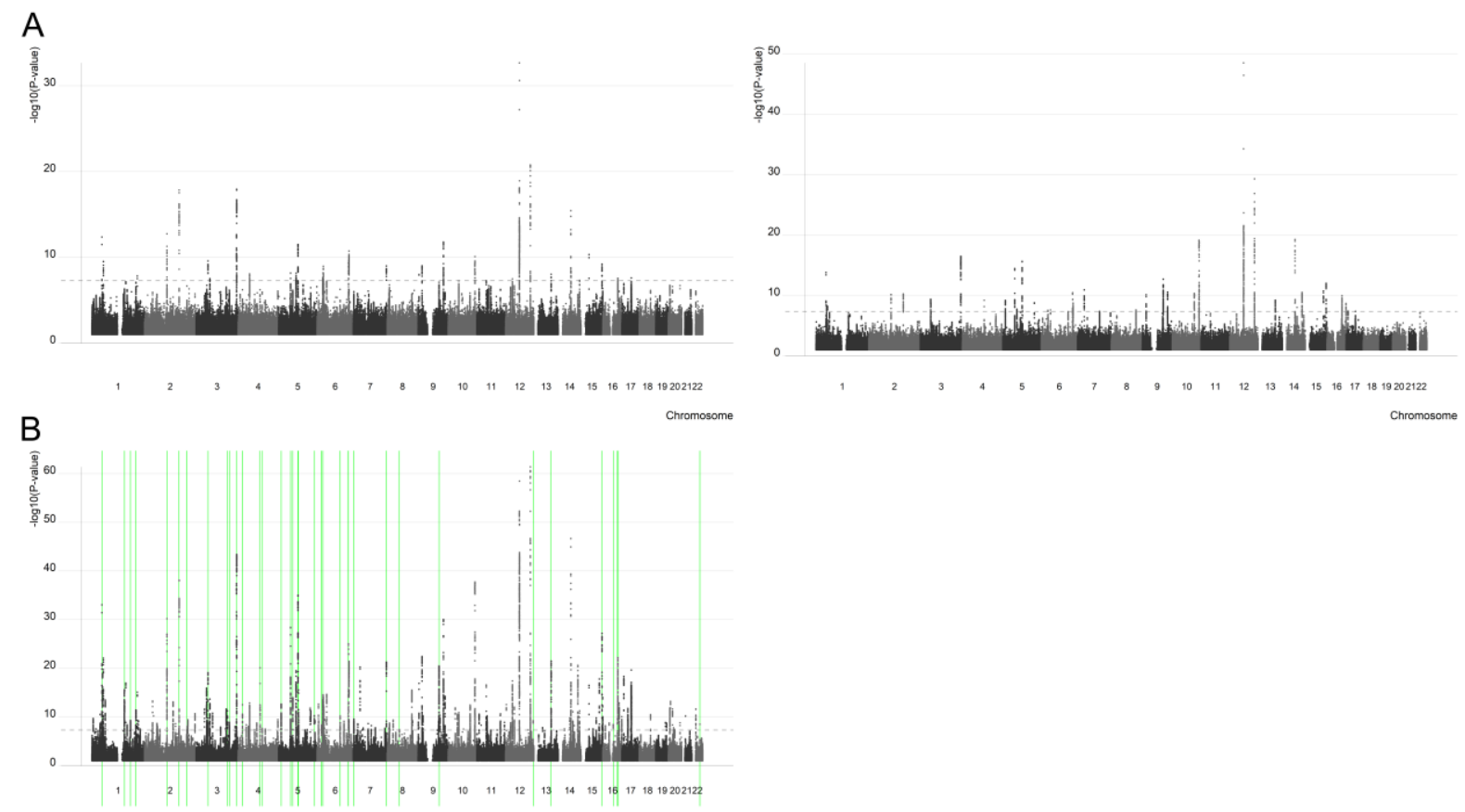

Supplementary Figure 3. Validation and replication. We performed two analyses to further assess the robustness of our findings. A) We randomly split the sample used in the main analysis in half and used one half as the discovery sample and the other as the replication sample. We performed a MOSTest analysis in both samples (the figure shows the corresponding manhattan plots) and calculated replication rates as an indicator of robustness of the MOSTest approach. From this split half analysis we found that $96.9 \%$ of the loci replicated at nominal P and $46.9 \%$ replicated at $5 \mathrm{e}-8$. B) We performed a cross-ethnic replication of the MOSTest analysis described in the main text using independent data from 5262 individuals with non-white ethnicity. $31.9 \%$ of the loci found in the full sample of white British individuals replicated at nominal $\mathrm{P}$ in the independent replication sample of non-white individuals (indicated with green lines). Given the small sample and differences in ethnicity, replication rates were fairly low yet met our level of expectation, in line with earlier work on other brain structures ${ }^{27}$. 
medRxiv preprint doi: https://doi.org/10.1101/2021.08.18.21262223; this version posted August 24, 2021. The copyright holder for this preprint (which was not certified by peer review) is the author/funder, who has granted medRxiv a license to display the preprint in All rights reserved. No reuse allowed without permission.

Distributed genetic architecture across the hippocampal formation | Bahrami et al.
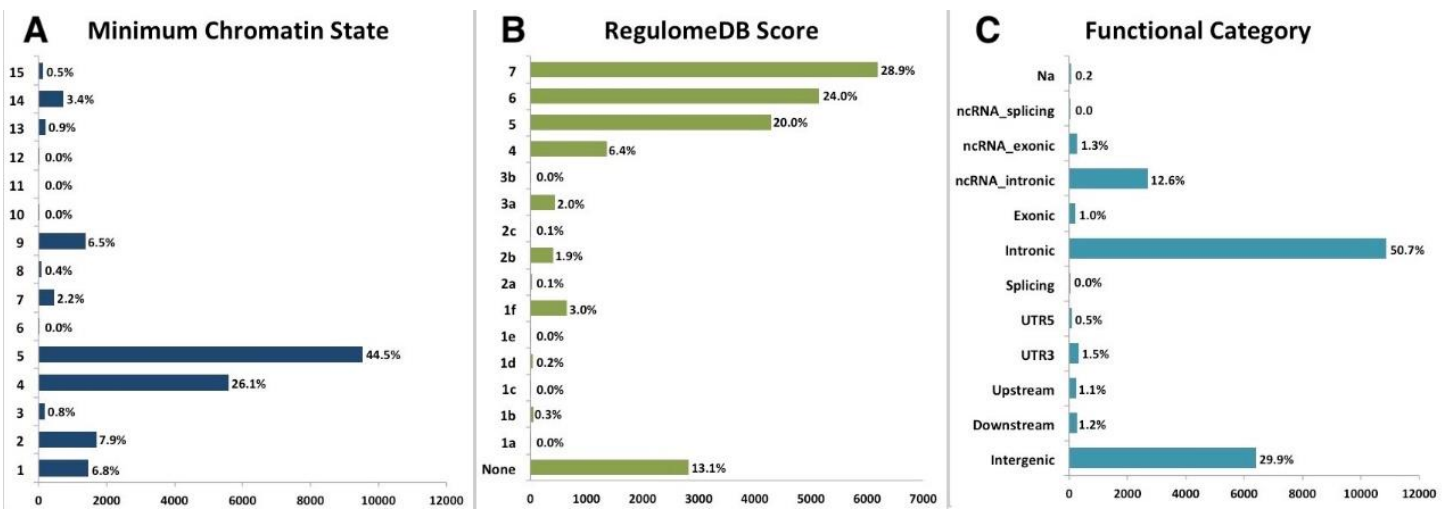

590 Supplementary Figure 4. Distribution of the annotation for all SNPs in the significant genetic loci from the hippocampus GWAS including (A) the minimum chromatin state across 127 tissue and cell types for SNPs in the significant genomic loci, with lower states indicating higher accessibility and states 1-7 referring to open chromatin states, (B) the distribution of RegulomeDB scores for SNPs in the significant genomic loci, with a low score indicating a higher likelihood of having a regulatory function and (C) the distribution of functional consequences of SNPs in the significant genomic risk loci. 
medRxiv preprint doi: https://doi.org/10.1101/2021.08.18.21262223; this version posted August 24, 2021. The copyright holder for this preprint (which was not certified by peer review) is the author/funder, who has granted medRxiv a license to display the preprint in perpetuity.

All rights reserved. No reuse allowed without permission.

Distributed genetic architecture across the hippocampal formation | Bahrami et al.
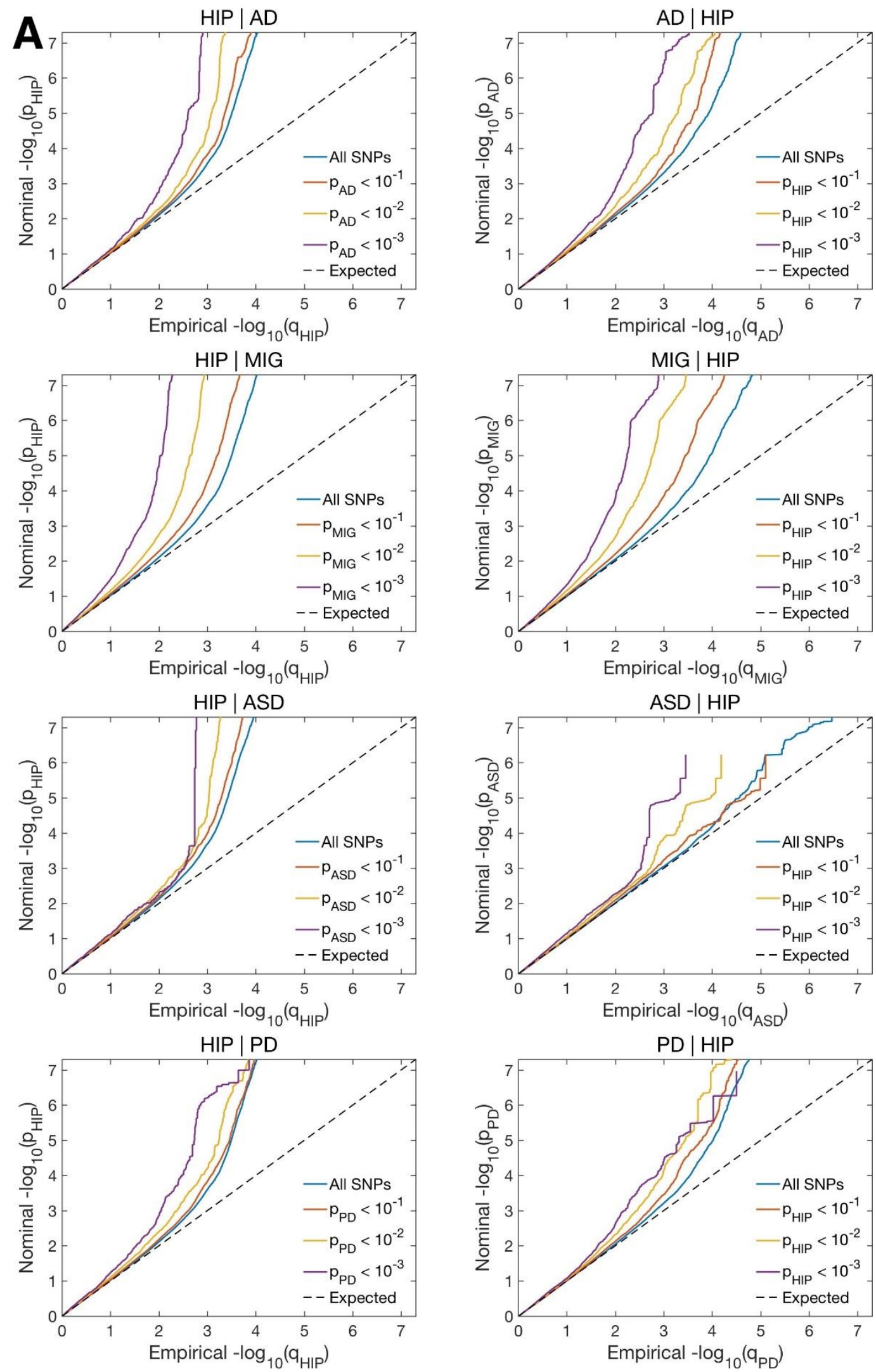
medRxiv preprint doi: https://doi.org/10.1101/2021.08.18.21262223; this version posted August 24, 2021. The copyright holder for this preprint (which was not certified by peer review) is the author/funder, who has granted medRxiv a license to display the preprint in perpetuity.

All rights reserved. No reuse allowed without permission.

Distributed genetic architecture across the hippocampal formation | Bahrami et al.
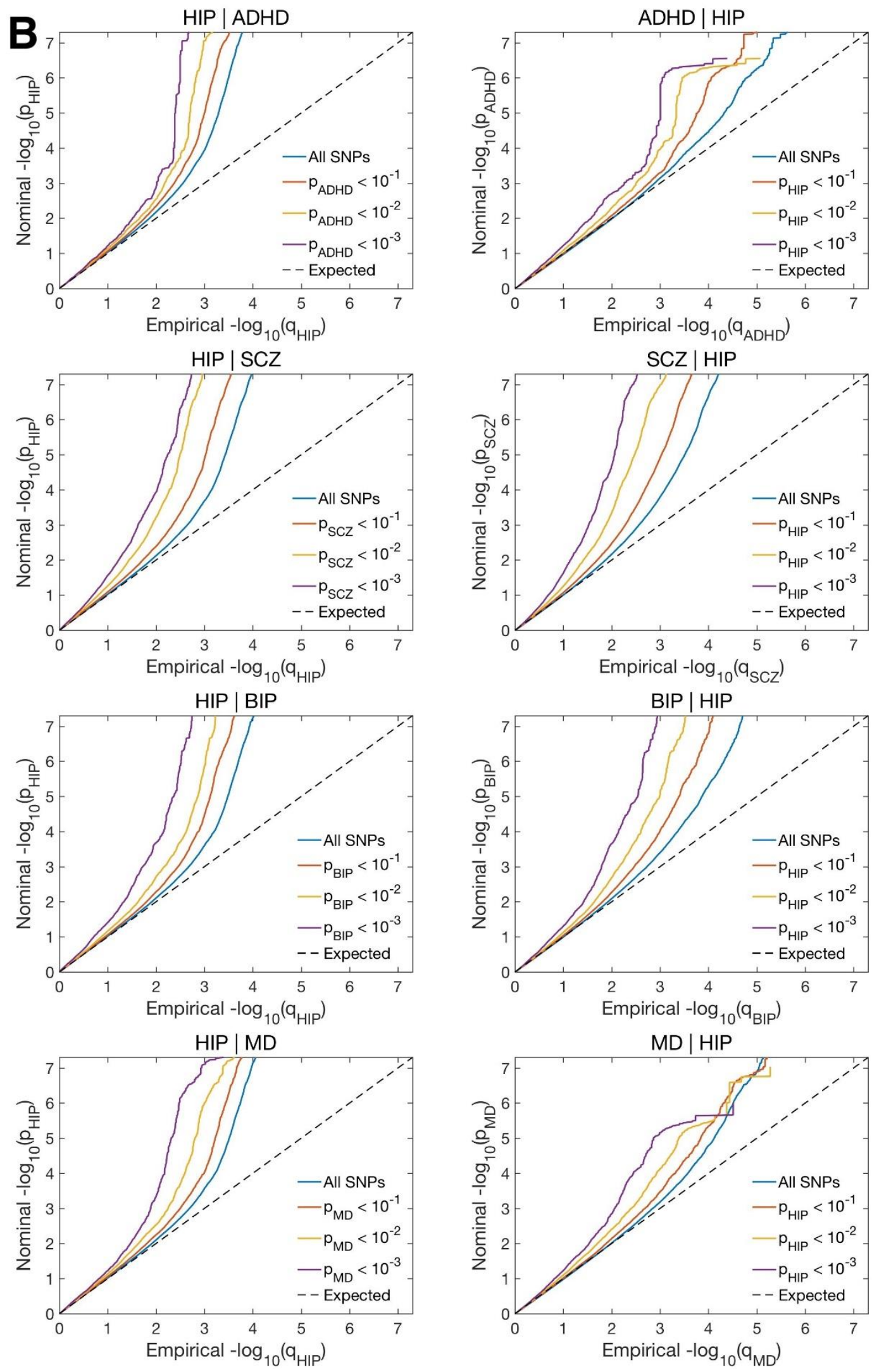

Supplementary Figure 5. Conditional Q-Q plots for hippocampus given associations with the disorder (left figures) and vice versa (right figures). ADHD: attention deficit hyperactivity disorder. AD: Alzheimer's disease. MIG: migraine. ASD: autism spectrum 603 disorder. PD: Parkinson's disease. SCZ: schizophrenia. BIP: bipolar disorder. MD: major depression. 